\title{
Influence of Geology and Groundwater Fluctuation on the Instability of Road Pavement between Shango and Paiko along Minna - Lambata Road, Central Nigeria
}

\author{
S.H. Waziri ${ }^{1}$, C.O. Okogbue ${ }^{2}$, N.M. Waziri ${ }^{1{ }^{1 *}}$, I.N. Abdullahi ${ }^{1}$ \\ ${ }^{1}$ Department of Geology, Federal University of Technology, Nigeria \\ ${ }^{2}$ Department of Geology, University of Nigeria, Nigeria
}

Copyright $(2015$ by authors, all rights reserved. Authors agree that this article remains permanently open access under the terms of the Creative Commons Attribution License 4.0 International License

\begin{abstract}
The geology and groundwater condition of the area was studied with the aim of understanding their impact on the instability of the road in the study area. These include the petrology, geophysics and groundwater fluctuation (percentage in water table fluctuation). The methodology included geological field mapping, thin section preparation, resistivity and water table monitoring in dry and wet seasons. The study reveals that the road is underlain by schist, amphibolites and poorly fractured granite with quartz, biotite, hornblende and muscovite as the constituent minerals. The rocks have been altered through weathering to clayey minerals with resistivity values as low as $14 \mathrm{Ohm}$ with the depth of weathering as high as 20 meter especially in the schist. The percentage of groundwater variation ranges between $154 \%$ and $2400 \%$ indicating medium to very high percentage of variation of groundwater fluctuation. These clay minerals absorb water and swell during the raining season and dry during the dry season. The result is the instability of the road pavement especially within the schist and where the elevation is lower. Proper design of the road and the provision of good drainage that will reduce the ingress of water are advised.
\end{abstract}

Keywords Geology, Road Failure, Consistency Limits, Minna, Water Table

\section{Introduction}

One of the most relevant geological factors investigated when choosing the route for a highway is the geology as well as the hydrogeology of the route. This help to determine the stability of the area. Geology and hydrogeologic conditions is one of the critical factors discovered by $[1,2,3]$ in the stability of a highway pavement. Examination is made in this paper on the influence of geology and groundwater fluctuation on the instability of the highway between Shango and Paiko, Central Nigeria.

\subsection{Factors Controlling the Instability of Highways}

Geologic/ hydrogeology, soil, climatic and drainage are among the most critical factors contributing to pavement instability as revealed by [3-7]. Disintegration of the underlying materials, lack of proper drainage that aid the ingress of water in to the pavement structure and loss of strength in the shoulders have been associated to pavement failure by Gidigasu [7]. The downward movement of rain water during the wet season reduces the strength of material underlying the road pavement while the soil moisture under the road reduces as a result of evaporation of soil water from the clayey shoulder material during the dry season. The use of substandard base and sub-base materials could also result to road failure. Investigations by Okagbue and Uma [3] and Russan and Croney [8] have also shown that depth to water table seems to be the most important of the climatic, topographic and drainage factors that affect road performance. The geology, rainfall and topography generally determine the depth to water table in an area.

\subsection{The Study Area}

The topography of the Minna area is largely controlled by the geology that comprises of schist, amphibolites and granites which forms part of the Basement Complex rocks of Nigeria. The geology of Minna area reveals that the schist has been intruded in places by the older granite (figure 1 and 2 ) that has led to intense jointing and fracturing of the schist. The schist is fine grained, foliated and dips at about $50^{\circ}$. Most of the drainages cut the narrow valley and water moves from the hills to the valley during raining season. The schists are mostly exposed along these river channels (River Chanchaga). Drainage pattern is the trellis while the major river found along the road is the Chanchaga River which is a tributary of the Kaduna River. The granitic hills are massive undulating terrains that range from $300 \mathrm{~m}-800 \mathrm{~m}$ high above 
mean sea level. The study area is within the middle belt of Nigeria with an average annual rainfall of $1,100 \mathrm{~mm}$. Precipitation commences in the month of April, gets to maximum in August/ September and ends in October. Low temperatures of about $24^{\circ} \mathrm{C}$ are recorded in the months of August and September. High temperature is usually recorded during the months of January to March, at an average of $35^{\circ} \mathrm{C}$. The harmattan wind is experienced during December and February.

\section{Methodology}

Road grade elevations: A geographical Positioning System (GPS) was used in taking the road grade elevations.

Well water level fluctuation: Static water levels were measured from five hand-dug wells located very close to / along the road during the peak of the dry (April) and rainy (September) seasons. A water meter was used in taking the measurements while a GPS was used in taking the ground elevation as well as the co-ordinates of the wells. The total depths of the wells were also measured.
Geophysical survey: Vertical electrical sounding (VES) also referred to as electrical resistivity sounding was employed during this study. Current was passed into the ground by means of two electrodes called current electrodes $\left(\mathrm{C}_{1}\right.$ and $\left.\mathrm{C}_{2}\right)$ and potential drop was measured through a second pair of electrode called potential electrodes $\left(\mathrm{P}_{1}\right.$ and $\mathrm{P}_{2}$ ). The electrode spacing interval was constantly changed while maintaining a fixed location from the centre of the electrode spread.

Laboratory tests: Atterberg Limits tests were conducted on ten soil samples that were collected from ten trial pits along the portion of the studied road. The liquid limit (LL) and plastic limit (PL) were each determined with about 300 grams of soil samples passing $0.425 \mathrm{~mm}$ sieve in accordance with BS 1377 [9]. The difference between LL and PL gave the plasticity index (PI). The cone penetration method as described by Brain [10] was used. A graph of cone penetration versus moisture content was plotted both on a linear scale and a straight line graph obtained. The LL was taken as the moisture content at which the standard cone penetrated $20 \mathrm{~mm}$ into the soil paste. X-Ray diffraction was carried at the Nigerian Geological Agency, Kaduna.

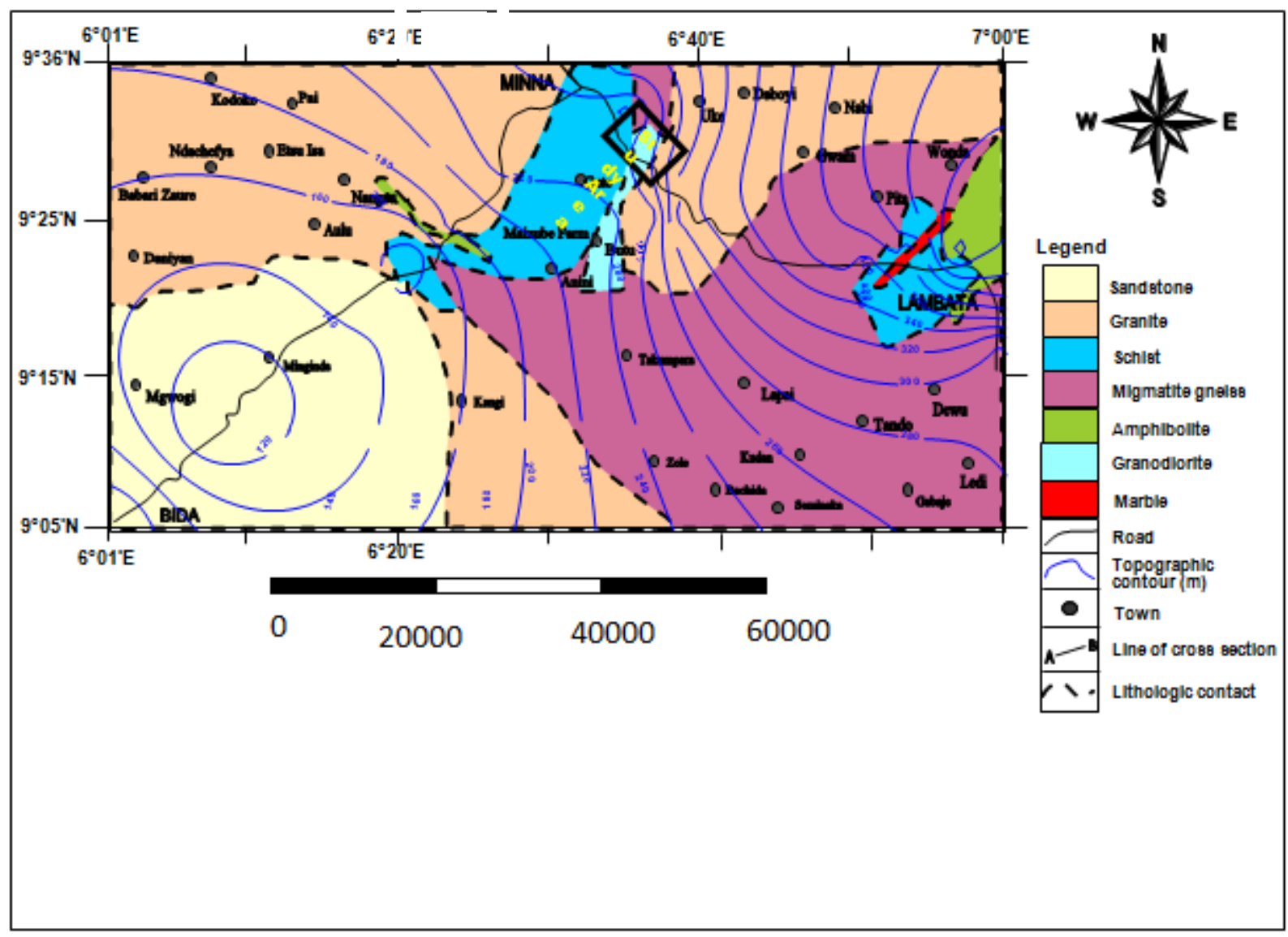

Figure 1. Geology of the study area. Study are is indicated as a rectangle in the top of the map. 


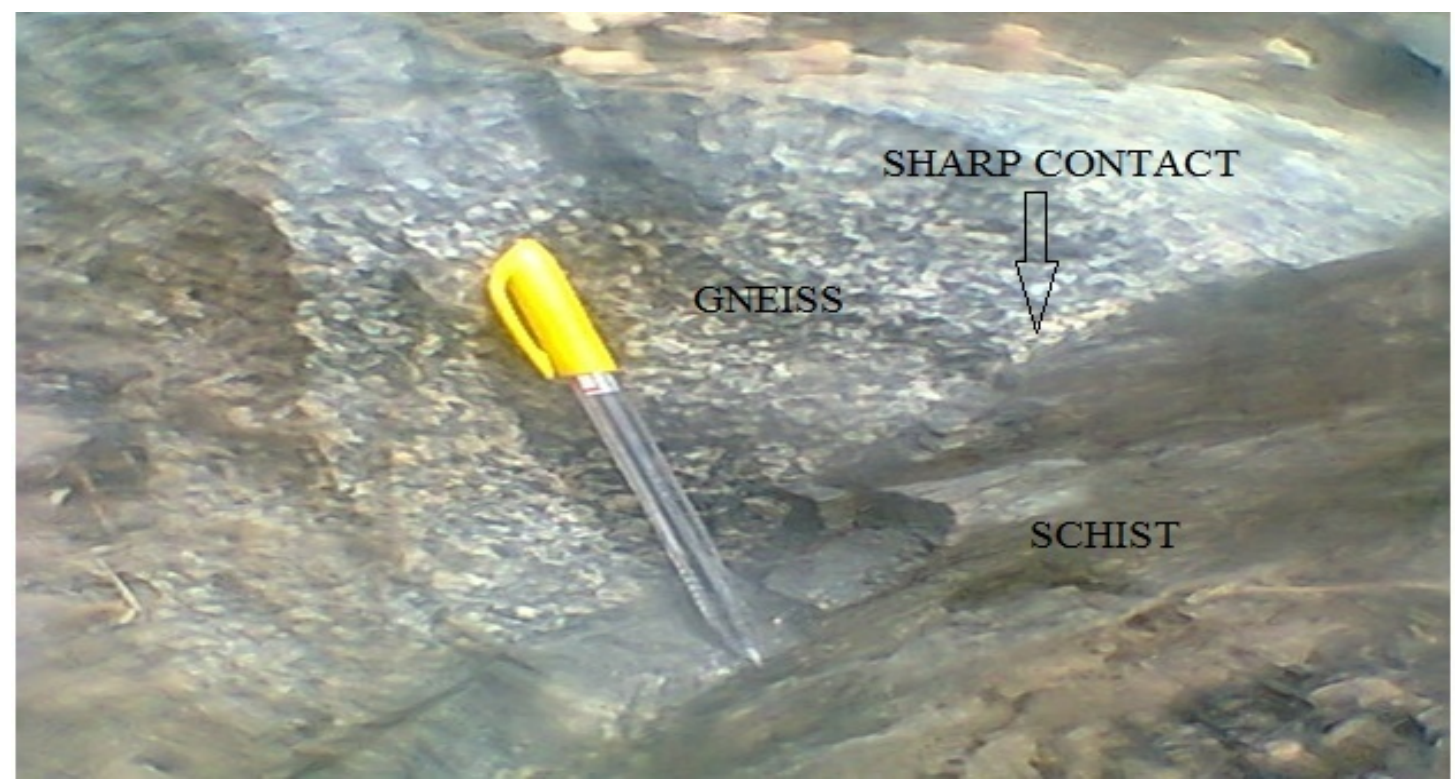

Figure 2. Schist intruded by granite gneiss in Minna area

Table 1. Groundwater fluctuation along Chanchaga - Paiko road

\begin{tabular}{|c|c|c|c|c|c|c|c|c|}
\hline Location & $\begin{array}{c}\text { Well } \\
\text { depth } \\
\text { (m) }\end{array}$ & $\begin{array}{c}\text { SWL } \\
\text { Dry Season A(m) }\end{array}$ & $\begin{array}{c}\text { SWL } \\
\text { Wet Season B(m) }\end{array}$ & $\begin{array}{l}\text { Variation } \\
(\mathrm{A}-\mathrm{B})\end{array}$ & $\begin{array}{c}\% \text { of } \\
\text { Variation }\end{array}$ & Lat.(N) & Long.(E) & $\begin{array}{c}\text { Elev. } \\
\operatorname{amsl}(\mathbf{m})\end{array}$ \\
\hline PAIKO I & 3 & 2.4 & 0.1 & 2.3 & 2400 & $9^{0} 28^{\prime} 42.8^{\prime \prime}$ & $6^{0} 59^{\prime} 37.2^{\prime \prime}$ & 299 \\
\hline PAIKO II & 4.6 & 4.2 & 2.5 & 1.7 & 168 & $9^{0} 6^{\prime} 32.1^{\prime \prime}$ & $6^{0} 59^{\prime} 53 ; 6^{\prime \prime}$ & 302 \\
\hline PAIKO III & 4.2 & 4.0 & 2.6 & 1.4 & 154 & $9^{0} 26^{\prime} 33.2^{\prime \prime}$ & $7^{0} 00^{\prime} 07.0^{\prime \prime}$ & 397 \\
\hline PAIKO IV & 4.6 & $4 . .3$ & 2 & 2.3 & 215 & $9^{0} 25^{\prime} 56.9^{\prime \prime}$ & $6^{0} 57^{\prime} 37.3^{\prime \prime}$ & 446 \\
\hline PAIKO V & 3.0 & 2.8 & 0.8 & 2 & 350 & $9^{0} 25^{\prime} 56.2^{\prime \prime}$ & $6^{0} 56^{\prime} 56.8^{\prime \prime}$ & 472 \\
\hline $\begin{array}{c}\text { CHANCHAGA } \\
\text { I }\end{array}$ & 2.1 & 1.5 & 0.5 & 0.4 & 300 & $9^{0} 32^{\prime} 15.6^{\prime \prime}$ & $6^{0} 50^{\prime} 04.5^{\prime \prime}$ & 369 \\
\hline $\begin{array}{c}\text { CHANCHAGA } \\
\text { II }\end{array}$ & 5.4 & 4.5 & 1.5 & 3 & 346 & $9^{0} 32^{\prime} 33.5^{\prime \prime}$ & $6^{0} 50^{\prime} 02.0^{\prime \prime}$ & 362 \\
\hline $\begin{array}{l}\text { CHANCHAGA } \\
\text { III }\end{array}$ & 5.5 & 5.1 & 1.7 & 3.4 & 300 & $9^{0} 32 ‘ 47.2^{\prime \prime}$ & $\begin{array}{lll}6^{0} & 49^{\prime} & 48.0^{\prime \prime}\end{array}$ & 360 \\
\hline SHANGO & 8.2 & 5.0 & 1.9 & 3.1 & 263 & $9^{0} 34^{\prime} 25.9^{\prime \prime}$ & $6^{0} 49^{\prime} 26.6^{\prime \prime}$ & 365 \\
\hline
\end{tabular}

Table 2. Resistivity values ( $\Omega . \mathrm{m}$ ) for resistivity sounding profiling along Shango-Paiko road

\begin{tabular}{ccccccccccccc}
\hline $\mathbf{A} / \mathbf{B} / \mathbf{2}$ & $\mathbf{P 1}$ & $\mathbf{P 2}$ & $\mathbf{P 3}$ & $\mathbf{P 4}$ & $\mathbf{P 5}$ & $\mathbf{P 6}$ & $\mathbf{P 7}$ & $\mathbf{P 8}$ & $\mathbf{P 9}$ & $\mathbf{P 1 0}$ & P11 & P12 \\
\hline 1 & 346 & 112 & 473 & 369 & 140 & 171 & 196 & 315 & 219 & 368 & 1016 & 543 \\
2 & 193 & 61 & 210 & 129 & 29 & 107 & 94 & 148 & 90 & 228 & 1279 & 283 \\
3 & 42 & 33 & 181 & 73 & 48 & 111 & 62 & 76 & 49 & 221 & 2166 & 229 \\
5 & 42 & 30 & 217 & 84 & 86 & 121 & 59 & 43 & 35 & 189 & 5016 & 163 \\
6 & 38 & 38 & 202 & 83 & 67 & 122 & 61 & 32 & 35 & 152 & 6490 & 126 \\
8 & 40 & 23 & 204 & 107 & 85 & 141 & 67 & 27 & 39 & 95 & 2587 & 80 \\
10 & 41 & 33 & 253 & 111 & 104 & 184 & 77 & 27 & 49 & 83 & 2327 & 58 \\
12 & 39 & 34 & - & 128 & 171 & 232 & 85 & 27 & 61 & 70 & 373 & 30 \\
15 & 41 & 37 & 364 & 148 & 149 & 274 & 83 & 35 & 76 & 64 & 367 & 20 \\
20 & 45 & 57 & 355 & 196 & 193 & 400 & 111 & 45 & 90 & 39 & 433 & 28 \\
25 & 53 & 45 & 543 & 221 & 261 & 515 & 185 & 71 & 114 & 53 & 286 & 32 \\
30 & 90 & 91 & 629 & - & 313 & 609 & 138 & 74 & 140 & 59 & 240 & 44 \\
\hline
\end{tabular}


Table 3. Summary of the minerals from the studied rocks

\begin{tabular}{|c|c|c|c|c|c|c|}
\hline \multirow{2}{*}{ Sample no } & \multirow{2}{*}{ Longitude } & \multirow{2}{*}{ Latitude } & \multicolumn{4}{|c|}{ Minerals and their chemical formula } \\
\hline & & & $1^{\text {st }}$ & $2^{\text {nd }}$ & $3^{\text {rd }}$ & $4^{\text {th }}$ \\
\hline Granite & $06^{\circ} 38^{\prime} 08^{\prime \prime}$ & $09^{\circ} 25^{\prime} 568^{\prime \prime}$ & $\begin{array}{l}\text { Quartz } \\
\left(\mathrm{SiO}_{2}\right)\end{array}$ & $\begin{array}{c}\text { Muscovite } \\
\left(\mathrm{Kai}_{2}(\mathrm{Si}, \mathrm{Ai})_{4} \mathrm{O}_{10}(\mathrm{OH})_{2}\right)\end{array}$ & $\begin{array}{c}\text { Albite } \\
\left(\mathrm{Na}\left(\mathrm{AlSi}_{3} \mathrm{O}_{8}\right)\right.\end{array}$ & $\begin{array}{l}\text { Wulfrenite } \\
\left(\mathrm{Pb}\left(\mathrm{MoO}_{4}\right)\right)\end{array}$ \\
\hline Granodiorite & $06^{\circ} 34^{\prime} 55.0^{\prime}$ & $09^{\circ} 31^{\prime} 28.3^{\prime \prime}$ & $\begin{array}{c}\text { Zinc Aluminium } \\
\text { Silicate } \\
\left(\mathrm{Zn}_{27.23}\left(\mathrm{Si}_{137} \mathrm{Al}_{55} \mathrm{O}_{384}\right)\right)\end{array}$ & $\begin{array}{c}\text { Nacaphite } \\
\left(\mathrm{Na}_{2} \mathrm{Ca}\left(\mathrm{PO}_{4}\right) \mathrm{F}\right)\end{array}$ & $\begin{array}{c}\text { Strontium Cerium } \\
\text { Aluminium Silicate } \\
\left(\mathrm{Sr}_{4.0} \mathrm{Cs}_{1.1}\left(\mathrm{Al}_{12} \mathrm{Si}_{36}\right.\right. \\
\left.\left.\mathrm{O}_{96}\right)\right)\end{array}$ & $\begin{array}{l}\text { Ferriwinchite } \\
\left(\mathrm{NaCaMg}_{4} \mathrm{Fe}(\right. \\
\left.\mathrm{Si}_{8} \mathrm{O}_{22}\right)(\mathrm{OH}, \mathrm{F}) \\
2) \\
\end{array}$ \\
\hline Schist & $06^{0} 34^{\prime} 51.7^{\prime \prime}$ & $09^{0} 31^{\prime} 31.7^{\prime \prime}$ & $\begin{array}{c}\text { Ferroan } \\
\left(\mathrm{Ca}_{2}\left(\mathrm{Mg}, \mathrm{Fe}_{+2}\right)_{4}\left(\mathrm{Si}_{7} \mathrm{Al}\right)\right. \\
\left.\mathrm{O}_{22}(\mathrm{OH}, \mathrm{F})_{2}\right)\end{array}$ & $\begin{array}{c}\text { Albite, calcian } \\
\left(\left(\mathrm{Na}_{0.75} \mathrm{Ca}_{0.25}\right)\left(\mathrm{Al}_{1.26} \mathrm{Si}\right.\right. \\
\left.\left.{ }_{2.74} \mathrm{O}_{8}\right)\right)\end{array}$ & & \\
\hline
\end{tabular}

\section{Results and Discussion}

Table 1 shows a percentage variation between $154 \%$ and $2400 \%$. Areas underlain by schist and granodorite have values ranging from $300 \%$ to $346 \%$ (with the highest value opposite the $\mathrm{PW}$ gate at Chanchaga) indicating medium to high percentage of variation. The rocks here are highly weathered into clayey materials that are mostly impermeable to the flow of water. The low percentage of variation recorded between Pogo and Paiko is as a result of the sandy nature of the soil derived from the granitic rock underlying that segment of the road pavement. Some of the weathered materials are sandy in some portions thereby allowing downward movement of water resulting in low to medium percentage of variation. The road alignments in these segments are fairly stable. The percentage of variation around the road segment cutting through the Paiko granite recorded the highest percentage of variation (2400\%). Though soils encountered here are sandy, the underlying rocks are not fractured and therefore impermeable to the flow of water. The implication is that the road is very unstable in this area.

The competency of these rocks is not uniform and so they response to the stress imposed on them by the road (structure) and moving vehicles differently. These have resulted to weakening of the rocks that made them more susceptible to weathering. The granodorite and schist are fine grain in texture and they weather mostly to clayey materials that are impermeable. These clayey materials absorb water and swell when the dry season sets in and contracts at the dry season forming cracks that can extend beyond one meter into the subsurface.

This leads to settlement of the road that causes instability and failure. This is more pronounced when the road base cut through the clay (mottled horizon as is the case just after the NNPC depot at Pogo).

The granites encountered are medium to coarse grain in texture. These rock types weather into medium to coarse grain soils as observed along the road. Water easily percolates through these sandy soils since they are permeable. Where these rocks are fractured in the subsurface, the drainage conditions are improved and the road traversing such areas is relative stable. The soil profile in such geologic environments was observed to be characterized by the absence of mottled zones. However, where these granites are not fractured as the case with the Paiko area, the drainage conditions were observed to be poor as evidenced by the presence of mottled zones in the soil profiles. Road portions that transverse such geologic environments were noted to be unstable.

Table 2 is the result of the subsurface as revealed by geophysical survey. The resistivity values ranges from 29 to 6490.The values are highest at the topmost layers $(0-2 \mathrm{~m})$, dropping from about 3-15 m indicating a loose weathered zone that is mostly wet and clayey. These very low resistivity values are seen to extend $20 \mathrm{~m}$ in some locations which signifies that the depth of weathering is more than 20 meters. The soils in these locations are mostly plastic in nature and weak and are easily deformed when load is imposed on them. This is the case between PW gate and Paggo (NNPC depot). This area is underlain by schist and granodiorite. The low resistivity indicates that the soils here are clayey and also contain some moisture. This have resulted to highly unstable road portion as experienced along the two road especially where the road base is laid directly on the $\mathrm{C}$ horizon or mottled zone. This further shows that the depth to basement (fresh rock) as well as the thickness of overburden varies considerably within the study area.

The X-ray diffraction analysis shows that quartz is found in the granites and the schist but absent in the granodiorite resulting in their mafic colouration. The table shows that the dominant minerals identified in the granite rocks include quart, feldspars, biotite, muscovite and hornblende while those identified in schist are biotite, muscovite, hornblende and lesser quartz.

Granite that is locally available was used as base course when the Shango-Paiko road was constructed. It therefore means that the instability experienced by the roads could not have been caused by the traffic density. Other sections of the road on higher elevations have not exhibited significant failures after 10 years of been used. It therefore means that the underlying geology, the subgrade soils and the design could be mainly responsible for the failure. Tables $1,2 \& 3$ shows that the soils that constitute the subgrade are the swelling types whose bearing capacity is usually low. The underlying geology that gave rise to the prevailing groundwater conditions and the subgrade material is thus responsible for the failure of this portion of the road. 
Observations from figure 1 show that the problem area is underlain by schist, granodiorites poorly fractures granites. The schists are found at a lower elevation and have been shown to be highly fractured and jointed due to the intrusion of the older granites in the Minna area. This intense fracturing and jointing has allowed the percolation of rain water, thus, considerably weakening the rocks and has transformed the rocks to unstable foundation material. The resulting lowered bearing capacity of the rocks and the subgrade is thought to have influenced the performance of the road at this portion. The studied rocks are made up of calcium-rich feldspars and dark minerals which are high in the weathering order (i.e., unstable). All these constituents have weathered to form amorphous hydrous oxides and clay minerals. Some of the minerals identified in the metamorphic rocks in the study area include hornblende, biotite, chlorite and sericite. Because the mafic minerals (most weatherable) are concentrated in schists and amphibolites, they have become susceptible to weathering. This property has proved troublesome in engineering [11].

The weathered rocks have formed clay minerals mostly kaolinite and montmorillonite. According to Okeke [12] and Attewell and Farmer [13], the cative clay mineral that is responsible for the swelling in expansive soil is montmorillonite. The presence of secondary minerals (halloysite, illite and montmorillonite) is very important from the engineering point of view $[14,15,16]$.The granular structure (responsible for the desirable engineering properties) in some of the studied soils appears to have been lost upon working the soils resulting in an increase in the clay-size content and plasticity. This has resulted in the soils having lower strengths, high pore pressure and high swelling potentials.

Table 4. Classification of the soils based on Atterberg Limits along Shango-Paiko Road

\begin{tabular}{|c|c|c|c|c|}
\hline LL(\%) & PL(\%) & PI & $\begin{array}{c}\text { USSC } \\
\text { classification }\end{array}$ & $\begin{array}{c}\text { Plasticity } \\
\text { adjective }\end{array}$ \\
\hline 27.5 & 6.3 & 21.2 & CL & High \\
\hline 30 & 5.5 & 24.5 & CL & High \\
\hline 24.0 & 4.5 & 19.5 & CL-ML & Medium \\
\hline 21.5 & 1.5 & 19 & CL-ML & Medium \\
\hline 25 & 5.0 & 20 & CL-ML & Medium \\
\hline 33 & 4.0 & 29 & CL & High \\
\hline 40 & 2.9 & 37.1 & CH & High \\
\hline 38 & 3.3 & 34.7 & CH & High \\
\hline 48 & 4.0 & 44 & CH & Very high \\
\hline 38.5 & 15.4 & 23.1 & CL & High \\
\hline
\end{tabular}

The geologic/hydrogeologic conditions coupled with lack of good drainage facilities that have resulted in the subgrade having low bearing capacity could be responsible for the failed pavement. The knowledge of the geology/hydrogeology cannot be underestimated in the selection, design, construction and long-life span of every road. The sections of the Shango-Paiko highway connecting Minna to the Federal Capital Territory, Abuja that have continue to fail is caused by the geology/hydrogeology of the area. This portion of the highway is constructed on relatively jointed, fractured granite and weathered schist as a sub-grade that has low bearing capacity. Observations have shown that the investigated portions of the road fail frequently despite every repair that follows. Complete excavation of the subgrade materials that have lost their strength is always involved in each repair. The major problems of these portions of the highway are the low bearing capacity of the subgrade along with the poor drainage of the base course as shown above. The root of the problem must be taken into consideration when attempting to ameliorate the problem. Effective sub-base drainage facilities is required in order to inhibit excess moisture in the subgrade, which eventually affects the base and sub-base courses and leads to low resistance through wheel-load displacement to stability. The primary way in making sure that the subsurface is in good condition is to control the water that gets to the sub-base through the shoulders and the edges of the pavement. For this to be achieved, the sub-base materials need to be made more porous as well as putting a sub-base drain in place. In this way, capillary moisture will also be reduced. This will reduce the capillary moisture which is the second category of source of moisture in the sub-base. Construction of wide-shallow ditches that intercept and divert the water from the road will also be helpful.

\section{Conclusions}

The knowledge of the geology/hydrogeology is important in the selection, design, construction and long-life span of every road. Loss of time, resources, properties and lives can be as a result of the road failure, in cases where such hydrogeologic information has been neglected. In this study, schist, granodiorites and granites underlies the area covered by the highway, and the primary rock forming minerals have been transformed through weathering in to new minerals that are mostly clayey (montmorillonite, illite, kaolin). The plagioclase feldspars have been altered to clay minerals, soluble salts and silica. The portions of the roads that fail most are where poorly fractured granite lies and at a lower elevation where the schist has weathered to plastic clayey materials as well as an accumulation of groundwater discharge. Storage of groundwater has also increase due to blockage of a lot of the seepages resulting in brake down of sub base materials. The schist has weathered to plastic clayey materials that absorb water, swells and expands during the wet season and contracts during the dry season. This has led to wetting of the base and sub-base materials almost all the time during the wet season.

The groundwater level rise in the wet seasons and fall in the dry season could be responsible for the swelling and shrinkage of the clay minerals underlain by the road pavements that has led to the cracking of open and surfaced pavements, stripping of the surfaces, waviness and potholes. The provision of adequate sub-base drainage facilities will help minimize the influx of water in the subgrade. 


\section{REFERENCES}

[1] Weinert, H.H. (1960). Engineering petrology for roads in South Africa. In K.B. Woods (Ed.) Geology Handbook (pp. 21-25), New York, McGraw-Hill.

[2] Farquhar, O.C. (1980). Geologic processes affecting the stability of rock slopes along Massachusetts highways. Eng. Geol. 16, 135-145.

[3] Okagbue, C.O., and Uma, K.O. (1988). The impact of geology on the performance of a bituminous surfaced pavement - a case study from southern Nigeria. Journ. African Earth Sci., 7(1), 257-264.

[4] Clare, E., and Beaven, P.J. (1969). Oils and other road making materials in Nigeria. Brit. Road Res. Lab. Tech. Paper, No. 57.

[5] Tanner, J.S. (1963). A review of the methods of pavement design used in overseas territories and the performance of roads constructed by the various design method. Proc. 3rd Reg. Conf. Africa soil Mech. Found. Eng., 1, 93-100.

[6] Gidigasu, M.D. (1974). The degree of weathering in the identification of laterite materials for engineering purposes. Eng. Geol, 8, $213-266$.

[7] Gidigasu, M.D. (1983). Development of acceptance specifications for Tropical Gravel paving materials. Eng.
Geol., 19, 213-240.

[8] Russan, K. and Croney, J.D. (1961). Effect of climatic factors on subgrade conditions. Geotech., 11(1), 22-28.

[9] British Standards Institution. (1990). Methods of testing soils for civil engineering purposes, BS 1377. British Standards Institution, London.

[10] Rahn, P.H. (1996). Engineering Geology: An Environmental Approach. Upper Saddle River, Prentice Hall PTR.

[11] Brain, V. (1983). Laboratory works in soil mechanics. Granada publishing limited.

[12] Okeke, O. C.(2008): Distribution, characterization and improvement of expansive soils in parts of southeastern Nigeria for engineering construction. Unpublished $\mathrm{PhD}$ thesis, University of Nigeria, Nsukka, Nigeria.

[13] Attewell, P.B., and Farmer, I.W. (1976). Principles of Engineering Geology. Chapman \& Hall.

[14] Alexander, L.T. and Cady, J.G. (1962). Genesis and Hardening of Laterite in Soil. Tech. Bull. 1282 US Department of Agriculture.

[15] Hamilton, R. (1964). Microscopic studies of laterite formation. In A. Jungenus (Ed.), Soil micromorphology (pp. 269-278). Elsevier, Amsterdam.

[16] Townsend, F.C., Manke, G.P., and Parcher, J.V. (1969). Effects of remolding on the properties of laterite soils. Highway Res. Rec., 284, 76-84. 